\title{
Lobster diseases
}

\author{
J. E. Stewart \\ Fisheries Research Branch, Department of Fisheries and Oceans; P.O.Box 550, Halifax, \\ Nova Scotia, Canada B3J $2 S 7$
}

\begin{abstract}
A number of diseases affecting lobsters (shell disease, fungal infections and a few selected parasitic occurrences) are described and have been discussed briefly. The bacterial disease, gaffkemia, is described in more detail and used insofar as possible to illustrate the interaction of a pathogen with a vulnerable crustacean host. Emphasis has been placed on the holistic approach stressing the capacity of lobsters and other crustaceans to cope with disease through flexible defense mechanisms, including on occasion the development of resistance.
\end{abstract}

\section{INTRODUCTION}

Although lobsters in their natural environments and in captivity are exposed to a wide range of microorganisms the list of diseases to which they are recorded as being subject is not lengthy. The list, however, will undoubtedly lengthen as studies on the lobsters continue and in particular as attempts to culture lobsters proceed.

Lobsters in keeping with other large and long lived crustaceans appear to be reasonably equipped to deal with most infectious agents. They possess a continuous sheath of chitinous shell or membranous covering composed of several different layers more or less impervious to normal wear and tear. In addition, once this barrier is breached a battery of intrinsic defenses is available to confine or destroy disease agents. These include rapid formation of a firm non-retracting hemolymph clot, bactericidins, agglutinins, phagocytic capacity or encapsulation and melanization. All of these serve the lobsters well until the animals are faced with an infectious agent which through circumstance or unique capabilities is able to overcome these defenses.

The information on lobster diseases is confined mainly to representatives of the genus Homarus. This comes about largely because the fishery for these lobsters is based upon the sale of the live animals which entails holding them for varying periods in captivity under conditions which range from satisfactory to completely adverse. This, coupled with the frequent attempts to culture lobsters, has produced greater opportunities and needs for studies of their diseases than is the case for many other invertebrates.

The lobster diseases for which some information is available are (a) shell disease, (b) infections caused by the fungi Fusarium sp., Haliphthoros milfordensis, and Lagenidium sp., (c) epibiontic growths, and (d) gaffkemia. Since these have been reviewed extensively over the recent past (Sindermann, 1970, 1971, 1977; Stewart \& Rabin, 1970; Stewart 1975, 1980; Rosen 1970; Fisher et al., 1978; and Sparks 1981), they will 
be treated here relatively briefly mainly in an attempt to illustrate the unique circumstances or capabilities which lead to an overt disease condition or abnormality.

Lobsters not only are important commercially, but offer many advantages as experimental animals for the study of crustacean mechanisms for protection against disease. They are relatively abundant, although expensive, large (approximately half a kilogram at maturity, the approximate minimum size in commercial fisheries), relatively easy to maintain, and the healthy animal has an easily accessible, sterile and large volume of blood or more properly hemolymph. Although the hemolymph of healthy animals is sterile, animals can acquire transient infections from trauma associated with handling and experimental procedures. Cornick \& Stewart (1966) for example found that as many as $20 \%$ of freshly captured lobsters had bacteria in their hemolymph, Micrococci, pseudomonads, Brevibacterium and Achromobacter, bacteria common in the marine environment. These were non-pathogenic and disappeared within a few days. Presumably they had entered adventitiously from the environment through wounds induced by rough treatment. These kinds of infections should not be termed diseases nor mistaken as such.

\section{SHELL DISEASES}

Rosen, 1970, in his review, defined shell disease as a single syndrome manifesting itself by progressive chitinolysis and necrosis of the exoskeleton of aquatic crustaceans. Shell disease in Homarus has been reviewed also by Sindermann $(1970,1971)$ and Fisher et al. (1978) and Stewart (1980).

The syndrome appears to be universal among crustaceans from the subarctic to the subtropics in fresh and marine waters wherever crustaceans occur. In Europe, the causative agents are considered to be several different fungi and it occurs in lobsters, some crayfish species, a crab and a number of non-commercial species of crustaceans where it is called "burn spot disease". In North America, the disease has been studied most extensively in lobsters and is regarded as bacterial in origin.

The disease was first recorded for lobsters by Hess (1937) who observed an epidemic of peculiarly "pitted" shells among live lobsters impounded for several months during the winter of 1935-1936. All parts of the shell were attacked (body, tail, legs, and claws), the lobsters were weak and required careful handling if the death of the animals was to be avoided. Hess isolated chitin digesting, gram negative bacteria from the lesions; he believed these were identical to Bacillus chitinovorus. His attempts to reproduce the disease using pure cultures of these bacteria were unsuccesful, although subsequent work (Taylor, 1948) suggested that the disease was contagious.

Despite the many questions surrounding the etiology of shell disease there is agreement on the major aspects of its development. The epicuticle (consisting of a very thin layer of proteolipid material including polyphenols) must be breached, possibly by mechanical abrasion, under circumstances which prevent its ready repair. This must occur in the presence of adequate numbers of chitinoclastic microorganisms which then attack the two underlying chitinous layers, exocuticle and calcified endocuticle, but virtually never attack the non-calcified endocuticle. The reason for the high levels of mortalities observed among lobsters affected is not clear.

Rosen (1970) believed that the necrotic pits, which develop, act as niches where 
several taxonomic groups interact to cause the general effect. The fact that the condition does not penetrate to the underlying soft tissue led Rosen to believe that affected animals would overcome the disease by molting. This, in fact, does occur and was observed by him for the blue crab (Callinectes sapidus) and by Wilder \& McLeese (1964) for the American lobster, Homarus americanus.

Malloy (1978) reinforced the foregoing with experiments with lobsters where he observed the development of shell disease only in those shell areas abraded prior to direct application of Vibrio sp. originally isolated from shell diseased lobsters. He observed that more infections were established among lobsters recovering from ecdysis than among those approaching it; more infections were established between 2 and $5^{\circ} \mathrm{C}$ than at higher temperatures.

The crucial point with shell disease for lobsters and for other crustaceans appears to be the rupture of the epicuticle, a layer generally impervious to biochemical attack. Possible causes of the failure to restore the epicuticle could be further mechanical damage, increasing enzymatic exploitation of the underlying passive layers through microbial development, adverse temperatures, inadequate diet and sustained pollution of particular types. The findings of Malloy are consistent with this in that the progress of the disease was greatest in lobsters with newly formed, weaker shells and at lower temperatures where the lobster would be metabolically less active and thus less able to effect epicuticular repair. Interestingly, Fisher et al. (1978) reported that diet was an important factor in establishing shell disease among juvenile American lobsters. The data showed that the rapidly growing animals fed an apparently inadequate synthetic diet were virtually devoid of the epicuticle in comparison to those fed on brine shrimp. Mortalities from shell disease among juvenile lobsters fed this synthetic diet reached almost $80 \%$; gram negative chitinolytic bacteria were isolated from the lesions of all the affected lobsters.

\section{FUNGAL DISEASES}

According to Unestam (1973), who based his statement on a simple count of citations, fungi outnumber the bacteria as pathogens of invertebrates. Johnson (1968, 1970), however, has expressed the view that most observations made on marine flora and fauna lacked definitive experimental evidence to confirm that the fungal associations were, in fact, pathogenic in nature. Many of the reports are limited to recording the presence of the fungal infestations and fail to provide identification, quantitative data or continue the observations for sufficient periods to be able to describe the effects in the host. Thus, the apparent predominance of fungal diseases among invertebrates may be more apparent than real. It should be noted, however, that these statements do not apply to Unestam and his co-workers who have given us a model to follow in their excellent and thorough studies on Krebspest, the devastating plague of the freshwater cray fish, Astacus astacus caused by Aphanomyces astaci. This disease has virtually eliminated this crayfish in many parts of Europe.

In the natural environment, adult lobsters of all genera seem to be generally free of fungal infections. Because of the intensive fisheries for lobsters and their use as food it is unlikely that external infestations or deep seated mycoses would go unnoticed among the many thousands of lobsters consumed annually. This generalization does not apply 
to the larval or immature forms for which similar extensive examinations are not made.

The bulk of the reports of fungal infestations of lobsters have been provided by studies of cultured Homarus americanus. These have been reviewed by Sindermann (1977), Fisher et al. (1978) and Stewart (1980). The first fungal disease of lobsters was reported by Herrick (1909) as being seen as early as 1902 among hatchery reared lobster larvae at Woods Hole. The "fungus spread from the point of the infection until all of the animal's tissues were destroyed and the lobster's body was reduced to a chitinous shell packed full of the mycelium".

Lightner \& Fontaine (1975) examined a group of immature lobsters (86 mm overall length) which had suffered $35 \%$ mortalities over a 12 month period. The lobsters were held in a closed water system at temperatures between 18 and $24^{\circ} \mathrm{C}$ at normal salinity and fed an experimental moist diet. The mortalities were attributed to a "black spot" condition on the exoskeleton. The "black spot" animals fed well and behaved normally but did not survive the next molt. Hyphae and conidia tentatively identified as belonging to a species of the genus Fusarium were observed on the gill lamellae. Histological sections from the exoskeleton showed the presence of hyphae in the cuticular and subcuticular tissues. The hyphae were encapsulated by hemocytes the first layer, of which, was melanized, Lightner \& Fontaine considered the infection to be very similar to the Fusarium infection of the Kuruma prawn, Penaeus japonicus known as "black gill disease" (Egusa \& Ueda, 1972).

Two phycomete infestations of larval and juvenile lobsters were recorded for animals reared in a semiclosed, recirculating seawater system operated at $20^{\circ} \mathrm{C}$ (Fisher et al., 1978). Haliphthoros milfordensis, the apparent cause, was confined to postlarval juvenile forms and affected both American ( $H$. americanus) and European ( $H$. gammarus) lobsters killing as many as $44 \%$. Fungal invasion normally occurred at two places: (1) beneath the carapace extending throughout the gill area and into the underlying muscle tissue; and (2) at the soft flexible joints of the appendage. Death was considered to be a result of destruction of tissue and/or impaired molting. In the muscle the spreading mycelium was heavily encapsulated and melanized; this did not occur in the gills. Fisher et al. suggest that entry may have been effected through minor wounds or possible weak chitinolytic action on the part of the fungus; the disease only affects juvenile lobsters with light integuments. The larger lobsters with heavier integuments apparently can ward off the infection and even in the smaller animals (less than $27 \mathrm{~mm}$ ) the fungus was not seen on the thicker parts of the integuments.

The second phycomycete is a ubiquitous fungus of the genus Lagenidium (Nilson et al., 1976) that replaced the internal tissues of the American lobster larvae. The fungus was found in a majority of groups of animals suffering mortalities as high as $90 \%$ or more. Mortalities were confined to the larval forms with death occurring within 49 to $72 \mathrm{~h}$ in an affected system. Fisher et al. (1978) suggested that the thicker exoskeleton of post larval forms prevents their infection and thus confines the infection to the egg and larval stages.

Finally, Sordi (1958) reviewed by Sindermann (1970) and Unestam (1973) reported that two deuteromycetes, Didymaria palinuri and Ramularia branchiales (Fungi Imperfecti) parasitized the gills of the lobsters, Palinurus vulgaris and $H$. vulgaris causing mortalities in the aquarium at Livorno. It is significant that these infections as in the other fungal diseases reported above occurred under similar circumstances, i.e. in 
aquaria using recirculating seawater systems and high, relatively constant temperatures.

The nature of such systems and the characteristics of the fungi (euryhaline and growing well at temperatures in the upper part of the lobsters temperature tolerance range) would be expected to place the lobsters at a disadvantage and favor development of the fungi. Recirculating systems are usually rich in dissolved nutrients especially suitable for microbial growth which, together with highly oxygenated water, would tend to increase the inoculum potential of the fungi. Thus, for lobsters stressed by enforced rapid growth with frequent molting and consequent integumental variation the conditions are optimal for the development of disease by the highly opportunistic fungi. Improved husbandry and improved quality of the water plus lower temperatures would probably be effective in reducing or eliminating the bulk of fungal infections experienced in these systems.

\section{EPIBIONTIC GROWTH}

Epibiontic growths in nature can include mussels, barnacles and seaweed; these are not considered serious under most circumstances and are lost upon molting. Filamentous microepibionts such as filamentous bacteria, stalked protozoans and diatoms are seen frequently in recirculating seawater systems (Herrick, 1909). The filamentous bacterium, Leucothrix mucor appears to be the most frequent offender (Fisher et al., 1978) and the only one positively identified to date. No mortalities have been specifically related to its occurrence on lobsters, but Fisher et al. suggested that it might assist in the establishment of fungal infestations and impair transport across gill and egg membranes. The potential for its occurrence is high since the organism is ubiquitous and noted for its ability to grow on simple organic compounds in well aerated waters over a wide temperature range. Thus, the conditions experienced in most recirculating systems contribute measurably to its development. Again, as for fungal diseases, the same recommended improvements in holding conditions and procedures for recirculating systems would seem to be appropriate; animals in single pass systems do not seem to develop either the fungal diseases nor the microepibionts to the same degree.

\section{LARGER PARASITES}

Read (1972) stated that "there are numerically more organisms living in someone else than there are organisms living the so-called free life". The list of parasites observed in Homarus americanus, $H$. vulgaris, and Nephrops norvegicus as listed in Stewart (1980) is representative rather than complete and bears out Read's statement fully. In general, the impact of the larger parasites on lobsters is not believed to be serious although in depth quantitative assessments have rarely taken place. Most parasitologists involved with lobsters believe strongly that this situation should be rectified. Various helminths, copepods and protozoa have been observed in all three species. Lists of certain of the occurrences are available in Stewart (1980).

\section{GAFFKEMIA}

The diseases or infections described above have been associated with the integument alone or obviously initiated their attack on the integument and then spread 
massively to underlying tissues in an often overwhelming manner. Where internal defenses were observed they consisted of hemocytic mobilization resulting in encapsulation and melanization.

The disease, gaffkemia, is quite unlike the foregoing in that it is caused by a gram positive coccus of known identity, Aerococcus viridans (var.) homari, which does not possess any invasive properties. In addition, it conducts all of its activities internally and its success is explained by its unique capacity to resist the lobster's internal defence mechanisms and flourish at the expense of the lobster's reserves. The disease has been reviewed comprehensively by Sindermann (1970, 1971, 1977), Stewart \& Rabin (1970), Stewart $(1975,1980)$, and Fisher et al. (1978).

The disease was first described by Snieszko \& Taylor (1947) who isolated a bacterium from moribund lobsters from a holding unit in Maine. Koch's postulates were fulfilled showing that the bacterium was a true pathogen of the lobster Homarus americanus. Because of its tetrad formation and association with lobsters, Hitchner \& Snieszko (1947) suggested the name, Gaffkya homari, by which it was known for years until the final taxonomic revisions were published in Bergey's Manual (Buchanan \& Gibbons, 1974). The original name of the causative agent provided the basis for the name of the disease, gaffkemia, coined by Roskam (1957).

The disease agent has been isolated from lobsters of the genus Homarus both feral and captive on both sides of the Atlantic (Stewart, 1980), where it has caused serious economic losses particularly in commercial holding operations. The disease appears to be endemic to the lobster populations of both $H$. americanus and $H$. vulgaris. The problems suffered from the disease are exacerbated by the usually adverse holding conditions apparent in many commercial operations and the extremely rough treatment frequently given in the lobster trade. In addition, many outbreaks of the disease are undoubtedly due to infections acquired in the holding units where the agent remains following previous slight to major problems with the disease. Sterilization of holding units is rarely, if ever, carried out. This, coupled with the fact that the organism is free living and quite capable of surviving in mud of pond bottoms, in detritus of tank units and plumbing for months, ensures that new epidemics will originate there (Goggins \& Hurst, 1960). The severity of the outbreaks will be governed largely by the temperatures prevailing during the course of the lobsters sojourn and subsequent treatment.

As mentioned above, A. viridans (var.) homari is free living and can be cultured readily using standard microbiological methods and media. It lacks external enzymes and thus invasive powers relying, instead, on opportunistic breaks in the lobster integument for transmission to an uninfected animal. Lobsters, although cannibalistic, do not acquire the infection by eating moribund or dead infected lobsters; the acidity of the gastric fluid is adequate to kill the ingested pathogen within a very short period.

The portal of entry is provided by a rupture in the lobster integument (caused frequently by the crowding and attendant fighting in commercial units) through which the pathogen passes. Whenever small numbers of a virulent strain of the pathogen $(10 / \mathrm{kg}$ lobster body weight) enter the hemolymph, a fatal infection almost invariably results. The times to death are approximately the same regardless of whether the initiating infection is large or small.

The bacteria concentrate and develop first in the hepatopancreas and cardiac tissues and upon reaching the decelerating logarithmic growth phase, they grow rapidly in the 
circulating hemolymph (Stewart \& Arie, 1973). The final numbers recorded for moribund lobsters are about $1 \times 10^{9} / \mathrm{g}$ or $\mathrm{ml}$ for hepatopancreatic tissue and hemolymph respectively and $1 \times 10^{8} / \mathrm{g}$ of cardiac or skeletal muscle tissue. The pathogen grows at the expense of the free glucose and non-protein nitrogen in the lobster; free glucose is generated by the lobster from its own glycogen stores. Declines in adenosine triphosphate (ATP), glycogen, circulating glucose and non-protein nitrogen among others suggest that death results from a massive dysfunction of the hepatopancreas.

An interesting addendum to this conclusion is provided by experiments conducted with fed and starved lobsters. Fed lobsters died from deliberately imposed gaffkemia infections in approximately one third of the time required for starved animals and with bacterial numbers 2 to 4 times higher than those observed for starved lobsters (Stewart et al., 1972). The rate of growth was controlled by the available nutrient level. These experiments also showed that infected lobsters cease feeding shortly after the onset of the infection $\left(2\right.$ days at $15^{\circ} \mathrm{C}$ ) a fact which should be taken into account in any disease survey work based upon trapping where an interest in food is a prerequisite for capture.

No toxin appears to be involved, massive transfusions of lobster hemolymph serum prepared from moribund gaffkemic lobsters and sterilized by filtration were given to healthy lobsters. Although amounts equal to $13 \%$ of the lobsters' weights were transfused (estimated to be around $30 \%$ of lobsters' hemolymph volumes) no deaths occurred and the lobsters appeared to be completely unaffected.

Among the features displayed early in the course of the infection is the decline in the numbers of circulating hemocytes, paralleling the increases of $A$. viridans (var.) homari in the hemolymph. The circulating hemocytes are virtually eliminated by the eighth day of the infection among lobsters held at $15^{\circ} \mathrm{C}$. Since the hemocytes carry the clot initiating factor (shown to be a transglutaminase in Panulirus interruptus by Fuller\& Doolittle, 1971) which in the presence of calcium, converts plasma fibrinogen to fibrin to give a hard non-retracting clot, their disappearance reduces and eventually eliminates the clotting capacity of the hemolymph even though the fibrinogen levels and other hemolymph proteins remain unchanged. Thus, if wounded, the lobsters at this stage can readily bleed to death. These overall results obtained by standard bacteriological and biochemical methods have recently been confirmed and extended in detail by histological studies done by Johnson et al. (1981).

The course of the infection is strictly temperature dependent. At $1{ }^{\circ} \mathrm{C}$ no deaths attributable to gaffkemia occurred over a 250 day trial among lobsters deliberately infected with the pathogen. The pathogen, however, did remain in the animals where all succumbed with a full blown infection after the temperature was raised. At $3^{\circ} \mathrm{C}$ the time between infection and death was about 180 days ranging downward to 2 days at $20^{\circ} \mathrm{C}$. It is important to note that the pathogen was able to survive $1{ }^{\circ} \mathrm{C}$ with its virulence unimpaired for periods much larger than temperatures this low are experienced in northern temperate zone waters; this is a significant epidemiological factor.

The early and massive permanent disappearance of the hemocytes led early to the belief that phagocytosis might be occurring early in the infection. It was shown, in fact that phagocytosis did occur and that the pathogen was enclosed within cells in the hepatopancreas and cardiac tissue within $15 \mathrm{~min}$ of injection. Unfortunately for the lobster this process is not adequate to ward off the infection. The pathogen survives and in fact grows at the expense of materials extracted from the hemocytes. The next step is 
the spillover of the bacteria to the hemolymph mentioned earlier. Disappearance of the hemocytes or a reduction of the number in circulation can also be caused by a variety of factors, although with other factors, a return to normal values is usually observed within hours or days at the most. Thus, in the course of the disease, gaffkemia, the intrinsic defense factors are either ineffective or, in the case of the phagocytes, are perhaps partially effective, but are unable to complete their task and are themselves destroyed without eliminating the pathogen.

The following hypothesis has been put forward to explain the apparent or presumed sequence of events occurring during the course of an infection of lobsters with $A$. viridans (var.) homari. The intact integument seems to be the only barrier to an active infection. Once the bacterium gains entry through a break in this barrier it comes in contact with the hemolymph which contains an inducible bactericidin, agglutinins, hemocytes and clotting. Although clotting has been shown to effectively seal off a wound very rapidly it is insufficient to confine the pathogen. The inducible bactericidin is absorbed readily in its inactive and active state by the pathogen. Although the bactericidin, upon activation by elements released by the hemocytes, is extremely effective against a wide variety of bacteria it is completely ineffective against $A$. viridans (var.) homari.

The agglutinins (Fig, 1) of the hemolymph which have been shown to agglutinate a wide variety of bacteria vary in concentration with the time of the year. This may be a
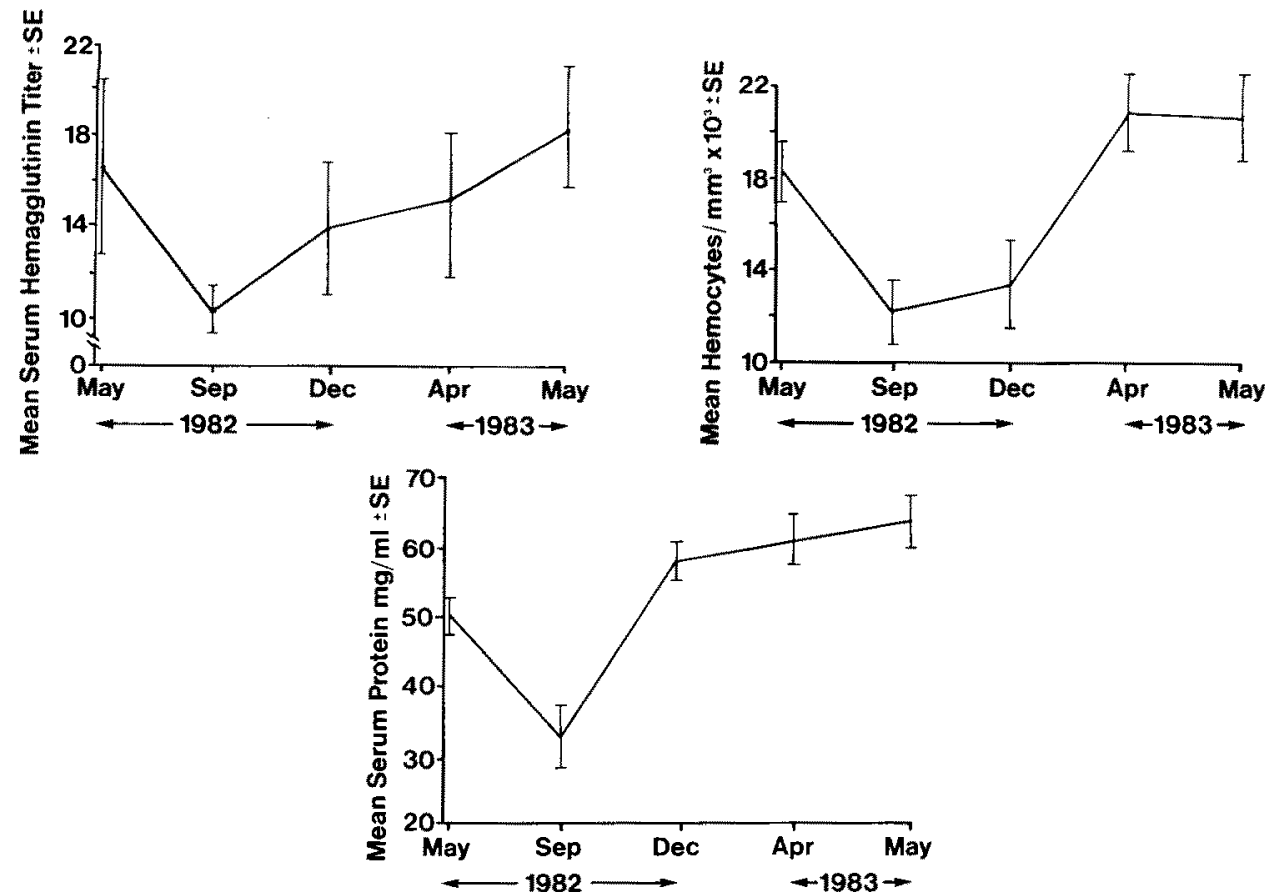

Fig. 1. Seasonal effects on lobster serum hemagglutinin titers (1a), lobster hemocyte numbers (1b), and lobster serum protein levels (1c). Individual values were determined for each date using groups of 20 lobsters freshly captured at Eastern Passage, Nova Scotia 
factor of significance for other infections, but it is not for $A$. viridans (var.) homari. Virulent strains of the pathogen are not agglutinated nor do they absorb the agglutinins; avirulent strains do absorb the agglutinins (unpubl. observ.). The explanation for the resistance of virulent strains to agglutination or absorption of the agglutinins in contrast to the results obtained with avirulent strains may lie with the differences exhibited in the capsular development. Virulent strains develop a large capsular layer while the avirulent strains possess virtually none (Fig. 2).

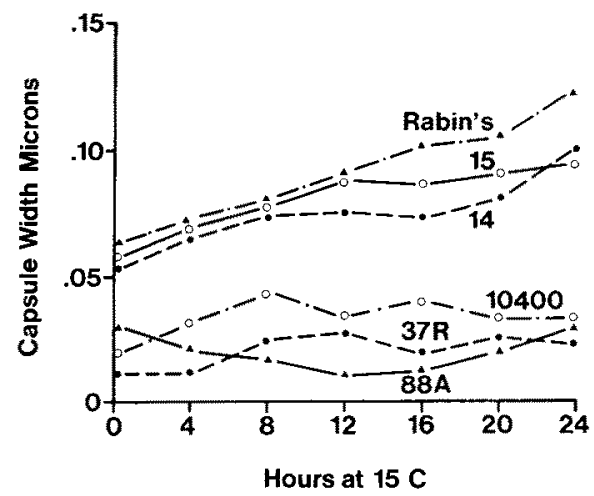

Fig. 2. Comparisons of the thickness of the capsular layers for strains of $A$. viridans (var.) homari during growth in normal lobster hemolymph serum over a period of $24 \mathrm{~h}$. Rabin's strain and strains 14 and 15 were of proven virulence determined by repeated trials in which fatal infections in lobsters developed after injection of these strains. The strains 10400, 37R and 88A were shown by similar trials to be avirulent

Thus the agglutinins do not afford protection as might be expected. If the agglutinins or some part of that fraction also have opsonic properties the failure to absorb these would reduce the effectiveness of phagocytosis in the first instance as a protective mechanism. It has been shown clearly that opsonins for other bacteria and red blood cells do exist in lobster hemolymph. Phagocytosis has been shown to be one of the properties of Homarus hemocytes (Paterson \& Stewart, 1974; Paterson et al., 1976; Paterson \& Stewart, 1979), but it has not been shown to be effective in aiding the normal animal to resist gaffkemia. Thus all of these systems fail for this particular pathogen.

Recent work on the lobster's mechanisms for resistance against disease has concentrated on elucidating the agglutinin and opsonin subject areas by using materials separated chromatographically from lobster hemolymph (Hall \& Rowlands, 1974; Hartman et al., 1978; Vanderwall et al., 1981; Goldenberg \& Greenberg, 1983). Goldenberg \& Greenberg were able to demonstrate differences in the properties of the agglutinin versus the opsonin, but were not prepared to state definitively that these were completely separate molecular entities. Hartman et al. and Vanderwall et al. on the other hand clearly isolated lectins which had differential agglutinin activities for different red blood cells. The activity of these fractions correlated well with the sialic acid content of the different red blood cells utilized. Unfortunately these fractions were not tested for opsonin activity.

In our work we have isolated these lobster hemolymph lectins following the 
procedures of Hartman et al. and confirm that the effects upon red blood cells is comparable to the results reported by these authors and Vanderwall et al. In applying these lectins to bacteria, however, we find that only a Brevibacter sp. is agglutinated in contrast to a wide range of bacteria agglutinated by untreated hemolymph serum. By the use of rabbit anti-sera specific for the purified lectins we have determined that these lectins are not absorbed as such from the hemolymph serum by sheep or human red blood cells or the Brevibacter sp. even though all three are agglutinated by the isolated lectins used alone. Thus, despite the excellent biochemical work of separating and characterizing these agglutinin components of the lobster hemolymph these studies have not provided answers resolving questions related to the lobster hemolymph agglutinating and opsonic activities as factors in disease resistance. If this aspect is to be advanced it will probably be necessary to use less artificial test systems with specific work directed to these questions.

The inducible parts of the lobster's defensive system observed to date appear to be confined to the non-hemocyte portion of the bactericidal system and the phagocytic capacity of the hemocytes. Agglutinin, opsonin and the slight precipitin activities have not been shown to be increased despite a number of attempts to induce these. The phagocytic index of hemocytes as well as the plasma and hepatopancreatic bactericidin levels can be increased readily by injections of a Pseudomonas perolens strain and by the endotoxin prepared from it.

Resistance to the pathogen $A$. viridans (var.) homari can be induced by vaccines prepared from virulent strains of the pathogen. Low level resistance to the pathogen (surviving challenges of $1 \times 10^{2} \mathrm{~A}$. viridans (var.) homari/kg lobster body weight) can be obtained routinely using formalin killed preparations of the pathogen. High levels of resistance (surviving challenges of $>2 \times 10^{5} \mathrm{~A}$. viridans (var.) homari/kg lobster body weight) can be induced by vaccines prepared using the antibiotic vancomycin in combination with virulent strains of the pathogen. The nature of the induced resistance is still to be determined.

Thus the infection of lobsters by $A$. viridans (var.) homari is prevented in nature only by an intact integument. Once this barrier is passed opportunistically the pathogen succeeds by virtue of its complete resistance to the comprehensive set of defense factors and its ability to grow well on the nutrients available within the lobster. The infection results in the death of the animal because the pathogen is more successful in the competition for the lobster's reserve materials than is the lobster.

\section{CONCLUSION}

Lobsters are generally well equipped in their natural environment to guard against most disease agents likely to be imposed. The various external infections (shell disease, fungal diseases and epibionts) seem to be products of peculiar environments and conditions more than specific weaknesses of the lobsters. Conditions which favor the pathogens and place the host at a disadvantage will always increase the potential for problems such as these. Good husbandry will probably aid in avoiding most or many of these diseases.

The disease gaffkemia, on the other hand, stems from the unique capacities of the pathogen to flourish in the internal environment of the lobster's body and cope ade- 
quately with or resist all of the defense mechanisms. In this case, a perfectly healthy animal succumbs to a highly specific pathogen.

Acknowledgements. I wish to thank B. Arie and L. J. Marks for their assistance in the preparation of this review.

\section{LITERATURE CITED}

Buchanan, R. E. \& Gibbons, N. E. (Eds), 1974. Bergey's manual of determinative bacteriology. Williams \& Wilkins, Baltimore, Maryland, 1268 pp.

Cornick, J. W. \& Stewart, J. E., 1966. Microorganisms isolated from the hemolymph of the lobster, Homarus americanus. - J. Fish. Res. Bd Can. 23, 1451-1454.

Egusa, S. \& Ueda, T., 1972. A Fusarium sp. associated with black gill disease of the Kuruma prawn, Penaeus japonicus Bate. - Bull. Jap. Soc. scient. Fish. 38, 1253-1260.

Fisher, W. S., Nilson, E. H., Steenbergen, J. F. \& Lightner, D. V., 1978. Microbial diseases of cultured lobsters: A review, - Aquaculture 14, 115-140.

Fuller, G. M. \& Doolittle, R. F., 1971. Studies of invertebrate fibrinogen. II. Transformation of lobster fibrinogen into fibrin. - Biochemistry 10, 1311-1315.

Goldenberg, P. Z. \& Greenberg. A. H., 1983. Functional heterogeneity of carbohydrate-binding hemolymph proteins: Evidence of a nonagglutinating Opsonin in Homarus americanus. - J. Invertebr. Pathol. 42, 33-41.

Hall, J. L. \& Rowlands, D. T., 1974. Heterogeneity of lobster agglutinins. I. Purification and physiological characterization. - Biochemistry 13, 821-828.

Hartman, A. L., Campbell, P. A. \& Abel, C. A., 1978. An improved method for the isolation of lobster lectins. - Dev, comp. Immunol, 2,617-625.

Herrick, F. H., 1909. Natural history of the American lobster. - Bull. U. S. Bur. Fish, 29, 149-408.

Hess, E., 1937. A shell disease in lobsters (Homarus americanus) caused by chitinovorous bacteria. J. biol. Bd Can. 3, 358-362.

Hitchner, E. R. \& Snieszko, S. F., 1947. A study of a microorganism causing a bacterial disease of lobsters. - J. Bact. 54,48 (abstr.).

Johnson, P. T., Stewart, J. E. \& Arie, B., 1981. Histopathology of Aerococcus viridans (var.) homari infection (gaffkemia) in the lobster, Homarus americanus, and a comparison with histological reactions to a gram negative species, Pseudomonas perolens. - J. Invertebr. Pathol. 38, 127-148.

Johnson, T. W. Jr., 1968. Saprobic marine fungi. In: The fungi. Ed, by G. C. Ainsworth \& A. S. Sussman. Acad. Press, New York, 3, 95-104.

Johnson, T. W. Jr., 1970. Fungi in marine crustaceans. In: A symposium on diseases of fishes and shellfishes. Ed. by S. F. Snieszko. Am. Fish. Soc., Washington, 405-408. (Spec. Publ. Am. Fish. Soc. 5.)

Lightner, D. V. \& Fontaine, C. T., 1975. A mycosis of the American lobster, Homarus americanus, caused by Fusarium sp. - J. Invertebr. Pathol. 25, 239-245.

Malloy, S. C.. 1978. Bacteria induced shell disease of lobsters (Homarus americanus). - J. Wildl. Dis. $14,2-10$

McLeese, D. W. \& Wilder, D. G., 1964. Lobster storage and shipment. - Bull. Fish. Res. Bd Can. 147, $1-69$.

Nilson, E. H., Fisher, W. S. \& Shleser, R. A., 1976. A new mycosis of larval lobsters (Homarus americanus). - J. Invertebr. Pathol. 27, 177-183.

Paterson, W. D. \& Stewart, J. E., 1974. In vitro phagocytosis by hemocytes of the American lobster (Homarus americanus), - J. Fish. Res. Bd Can. 31, 1051-1056.

Paterson, W. D. \& Stewart, J. E., 1979. Rate and duration of phagocytic increase in lobsters induced by Pseudomonas perolens endotoxin. - Dev. comp. Immunol. 3, 353-357.

Paterson, W. D., Stewart, J. E. \& Zwicker, B. M., 1976. Phagocytosis as a cellular immune response mechanism in the American lobster, Homarus americanus. - J. Invertebr. Pathol. 27, 95-104.

Read, C. P., 1972. Animal parasitism. Prentice-Hall, Englewood Cliffs, New Jersey, 182 pp.

Rosen, B, 1970. Shell disease of aquatic crustaceans. In: A symposium on diseases of fishes and 
shellfishes. Ed. by S. F. Snieszko. Am Fish. Soc., Washington, 409-415. (Spec. Publ. Am Fish. Soc. 5.)

Roskam, R. T., 1957. Gaffkaemia, a contagious disease in Homarus vulgaris. - C.M./ICES, Shellfish Commn Rep. 1, 1-4.

Sindermann, C. J., 1970. Principal diseases of marine fish and shellfish. Acad. Press, New York, $369 \mathrm{pp}$.

Sindermann, C. J., 1971. Internal defenses of Crustacea: A review. - Fish. Bull. U. S. 69, $455-489$.

Sindermann, C. J. (Ed.), 1977. Disease diagnosis and control in North American marine aquaculture. Elsevier, Amsterdam, 329 pp.

Snieszko, S. F. \& Taylor, C. C., 1947. A bacterial disease of the lobster (Homarus americanus). Science, N. Y., 105, 500.

Sordi, M., 1958. Micosi dei Crostacei decapodi marine, - Riv. Parasitol. 19, 131-137.

Sparks, A. K., 1981. Bacterial diseases of invertebrates other than insects. In: Pathogenesis of invertebrate microbial diseases. Ed. by E. W. Davidson. Allanheld, Osmun, Totowa, New Jersey, 323-363.

Stewart, J. E, 1975. Gaffkemia, the fatal infection of lobsters (genus Homarus) caused by Aerococcus viridans (var.) homari: A review, - Mar. Fish. Rev. 37 (5-6), 20-24.

Stewart, J. E., 1980. Diseases. In: The biology and management of lobsters. Ed. by J. S. Cobb \& B. F. Philipps. Acad. Press, New York, 1, 301-342.

Stewart, J. E. \& Arie, B., 1973. Depletion of glycogen and adenosine triphosphate as major factors in the death of lobsters (Homarus americanus) infected with Gaffkya homari. - Can. J. Microbiol. 19, 1103-1110.

Stewart, J. E. \& Rabin, H., 1970. Gaffkemia, a bacterial disease of lobsters (genus Homarus). In: A symposium on diseases of fishes and shellfishes. Ed. by S. F. Snieszko. Am Fish. Soc., Washington, 431-439. (Spec. Publ. Am Fish. Soc. 5.)

Stewart, J. E., Zwicker, B. M., Arie, B. \& Horner, G. W., 1972. Food and starvation as factors affecting the time to death of the lobster Homarus americanus infected with Gaffkya homari. - J. Fish. Res. Bd Can. 29, 461-464.

Taylor, C. C., 1948. Shell disease as a mortality factor in the lobster (Homarus americanus). - Fish Circ. Maine, Dep. Sea Shore Fish. 4, 1-8.

Unestam, T., 1973. Fungal diseases of crustacea. - Rev. Med. Vet. Mycol. (U. K.) 8, 1-20.

Vanderwall, J., Campbell, P. A. \& Abel, C. A., 1981. Isolation of a sialic acid-specific lobster lectin ( $\mathrm{L}$ Ag 1) by affinity chromatography on Sepharose-colominic acid beads. - Dev. comp. Immunol. $5,679-684$. 